UDC: 615.07:633.15:543.544.943.3

DOI: 10.15587/2519-4852.2017.108198

\title{
DEVELOPMENT OF METHOD FOR QUANTITATIVE ANALYSIS OF CORN SILK FOR INCLUSION IN THE DRAFT NATIONAL MONOGRAPH OF THE STATE PHARMACOPOEIA OF UKRAINE
}

\author{
(C) U. Karpiuk, E. Kotova, A. Kotov, V. Kyslychenko
}

Відповідно до концепції створення та введення до Державної Фармакопеї Украӥни монографій на лікарську рослинну сировину, кукурудзи стовпчики з приймочками відносяться до переліку лікарської рослинної сировини, шуо описана в Державній Фармакопеї СРСР ХІ видання і відсутня в Свропейській Фармакопеї, тому для цієї рослини актуальним є розробка національної монографії. Раніше повідомлялося, у Державній Фармакопеї СРСР ХІ видання відсутні методи кількісного визначення біологічно активних речовин даної сировини.

Мета. Розробка методик кількісного визначення флавоноїдів кукурудзи стовпчики з приймочками методом спектрофотометрії, гармонізованих з вимогами Державної Фармакопеї України до лікарської рослинної сировини для включення до проекту начіональної монографії «Кукурудзи стовпчики з приймочками».

Методи. Для досягнення поставленої мети використовували уніфіковані методики аналізу флавоноїдів методом спектрофотометрії.

Результати. Виходячи із хімічного складу, застосування у медицині та підходів до стандартизації, для ідентифікаиій методом спектрофотометрії обрані флавоноїди. Приведено результати кількісного визначення флавоноїдів у 7 зразках кукурудзи стовпчиків з приймочками методом спектрофотометрії.

Висновки. Обтрунтовано необхідність удосконалення існуючої нормативної документації на кукурудзи стовпчики з приймочками, яка б відповідала сучасним вимогам та була гармонізована з Свропейською фармакопеєю. В результаті проведених досліджень було запропоновано в начіональну монографію Державної фармакопеї Украӥни «Кукурудзи стовпчики з приймочками» включити методику кількісного визначення флавоноїдів, у перерахунку на лютеолін, із регламентацією не менше 0,6 \%

Ключові слова: стандартизаџія, Державна фармакопея України, кукурудзи стовпчики з приймочками, флавоноїди

\section{Introduction}

One of the most important sources for development of remedies is herbal material (HM). Its appropriate quality, guaranteed by proper cultivation, harvesting, drying, crushing and storage conditions, is mandatory condition for HM use [1]. Standardization of HM in accordance with the modern requirements also guarantees the appropriate quality of both herbs and remedies on its basis. The State Pharmacopoeia of Ukraine (SPH) monograph is a document regulating the quality of $\mathrm{HM}$ in Ukraine [2].

In the development of monographs on HM for the further implementation into the SPhU follow the guidelines of the European Pharmacopoeia [3]. One of the stages of HM standardization is the establishment of qualitative and quantitative parameters of its biologically active substances (BAS) [3, 4].

2. Formulation of the problem in a general way, the relevance of the theme and its connection with important scientific and practical issues

Corn silk is widely used herbal material which is included in the composition of many medicines, functional food products and commonly used in traditional medicine [5-7]. Corn silk quality is regulated in the USSR State Pharmacopoeia of the XI edition [8], in the State Pharmacopoeia of the Republic of Belarus [9], in the French Pharmacopoeia [10] and in the British Homoeopathic Pharmacopoeia [11]. Quantitative determination of BAS in Corn silk is absent in the all pharmacopoeias.
3. Analysis of recent studies and publications in which a solution of the problem and which draws on the author

Previously, the authors substantiated the necessity of the development of national monograph on such a widely used herb as Corn silk, which could meet the modern requirements [12] and was harmonized with the European Pharmacopoeia (PhEur) [13].

4. Allocation of unsolved parts of the general problem, which is dedicated to the Article

In the USSR State Pharmacopoeia of the XI edition there are no modern methods for identification of biologically active substances of the given herbal material, but there is identification only by macroscopic and microscopic diagnostic features. This approach does not allow objectively evaluating the quality of herbal material. The development of methods for quantitative determination of BAS in Corn silk is still unsolved problem.

\section{Formulation of goals (tasks) of Article}

The aim of the study was to establish the possibility of quantitative determination of flavonoids of Corn silk using unified spectroscopy method that would meet the State Pharmacopoeia of Ukraine requirements, and to investigate the possibility of the national monograph harmonization with the PhEur requirements.

The analysis was carried out in accordance with the requirements concerning the development of monographs on herbal material (HM), approved by the State 
Enterprise "Ukrainian Scientific Pharmacopoeial Center for Quality of Medicines" State Enterprise "Ukrainian Scientific Pharmacopoeial Center for the Quality of Medicinal Products" and work [14].

6. Statement of the basic material of the study (methods and objects) with the justification of the results Study of the herbal material.

7 samples of Corn silk were used as the research objects, some of them were purchased at the pharmacy, and the rest were harvested in different regions of
Ukraine in 2016 - Kharkiv, Mykolaiv and Kherson regions.

The data about the series, registration number (registration of the batch of herbal material as a research sample in the State Enterprise "Pharmacopoeia Center") and the place of harvesting and / or manufacturer for the preparation of test solutions are presented below (Table 1).

Determination of the quantitative composition of flavonoids in Corn silk was carried out by UV-Vis absorption spectroscopy method according to the $\mathrm{SPhU} 2.0$ $(2.2 .25)$.

Information about Corn samples

\begin{tabular}{|c|c|c|c|}
\hline No. & Batch number & Registration number & Harvesting place / Manufacturer \\
\hline 1. & $160516-1$ & RS 684 & Lozova, Kharkiv region \\
\hline 2. & $160516-2$ & RS 685 & Kherson region \\
\hline 3. & $160516-3$ & RS 686 & Kharkiv region \\
\hline 4. & $160516-4$ & RS 687 & Mykolaiv region \\
\hline 5. & $160516-5$ & RS 688 & Private Corporation Pharmaceutical factory "Viola" \\
\hline 6. & $160516-6$ & RS 689 & Private Joint Stock Company "Liktravy" \\
\hline 7. & $160516-7$ & RS 690 & \\
\hline
\end{tabular}

A unified method, based on the spectrophotometric determination of flavonoids after reaction with a mixture of boric and oxalic acids in a medium of formic and acetic acids, was used. It is used in several SPhU monographs to determine the flavonoid compounds in HM, which are mainly represented by flavones $[13,15]$, which is appropriate in the case of Corn herbal materials, taking into account the preliminary results of the chromatographic study of flavonoid compounds by TLC [16].

Luteoline SPhU standard sample (Pharmacopoeial standard sample of the $\mathrm{SPhU}$ ) was used as a reference solution. HP 8453 UV-VIS «Hewlett Packard» spectrophotometer, USA, was used for the optical density measuring and absorption spectra recording. All the used reagents met the $\mathrm{SPhU}$ requirements; their solutions were prepared according to the 4.1.1 chapter $[17,18]$.

Validation parameters of the given method were studied previously [19, 20]; it was determined that the method is suitable in the range of $0.5 \%$ to $2.5 \%$ of the sum of flavonoids.

Quantitative determination method.

Preparation of the initial solution 1. The analytical sample of the herbal material was grounded to particle size which passes through a number 355 sieve. About $0.250 \mathrm{~g}$ (exact weight) of the powdered herb were placed into the flask $200 \mathrm{ml}$ volume, $40 \mathrm{ml}$ of ethanol R $60 \%$ was added, heated in a water bath with condenser at $60{ }^{\circ} \mathrm{C}$ for $10 \mathrm{~min}$, and gently shaken by the rotational movement, washing the residue appearing on the walls. Then, the solution was cooled and filtered through cotton wool into a $100 \mathrm{ml}$ volumetric flask. The cotton wool with remnants of the herbal material was placed into the same flask $200 \mathrm{ml}$ volume, $40 \mathrm{ml}$ ethanol $R 60 \%$ was added, and it was heated in a water bath at $60{ }^{\circ} \mathrm{C}$ for $10 \mathrm{~min}$, shaking gently, then cooled and filtered into the same flask $100 \mathrm{ml}$ volume. Both the $200 \mathrm{ml}$ flask and the filter were washed by ethanol $R 60 \%$, washing liquid was placed into the same volumetric flask $100 \mathrm{ml}$ volume, and the mixture was diluted to $100 \mathrm{ml}$ by ethanol $R 60$ $\%$ and then filtered.

Preparation of the test solution. $5.0 \mathrm{ml}$ of the initial solution 1 was placed into round bottom flask and evaporated to dryness under reduced pressure. The obtained residue was transferred to a volumetric flask $25 \mathrm{ml}$ volume using $8 \mathrm{ml}$ mixture of methanol $R-$ glacial acetic acid $R$ (10:100), and the washing liquid was put into the same $25 \mathrm{ml}$ volumetric flask. $10.0 \mathrm{ml}$ of the solution was added to the obtained solution containing $25 \mathrm{~g} / \mathrm{l}$ boric acid $R, 20 \mathrm{~g} / 1$ oxalic acid $R$ in anhydrous formic acid $R$, and then diluted the volume to $25.0 \mathrm{ml}$ by glacial acetic acid $R$.

Preparation of the compensation solution $1.5 .0 \mathrm{ml}$ of the initial solution 1 was placed in the round bottom flask and evaporated to dryness under reduced pressure. The obtained residue was transferred into the volumetric flask $25 \mathrm{ml}$ volume using $8 \mathrm{ml}$ mixture of methanol $R-$ glacial acetic acid $R$ (10:100). The round bottom flask was washed by $3 \mathrm{ml}$ mixture of methanol $R-$ glacial acetic acid $R$ (10:100) and the washing liquid was placed into the same volumetric flask $25 \mathrm{ml}$ volume. $10.0 \mathrm{ml}$ of anhydrous formic acid $R$ was added to the obtained solution.

Preparation of the initial solution 2. $0.010 \mathrm{~g}$ (exact weight) of the luteolin Pharmacopoeial standard sample of the $\mathrm{SPhU}$ was placed into the volumetric flask $100 \mathrm{ml}$ volume, diluted in $70 \mathrm{ml}$ of methanol $R$, and then diluted the volume to mark by the same solution and mixed.

Preparation of the reference solution. $1.0 \mathrm{ml}$ of the initial solution 2 was transferred in the volumetric flask $25 \mathrm{ml}$ volume, $10.0 \mathrm{ml}$ of solution containing $25.0 \mathrm{~g} / 1$ boric acid $R, 20.0 \mathrm{~g} / 1$ oxalic acid $R$ in anhydrous formic acid $R$ were added and then the volume was diluted by anhydrous acetic acid $R$ to $25.0 \mathrm{ml}$.

Preparation of the compensation solution 2. 1.0 of the initial solution 2 was transferred in the volumetric flask $25 \mathrm{ml}$ volume, $10.0 \mathrm{ml}$ of anhydrous formic acid $R$ were added and then the volume was diluted to $25.0 \mathrm{ml}$ by anhydrous acetic acid $R$. 
Absorbance (2.2.25) of the test solution is measured after 30 minutes after preparation at a wavelength of $410 \mathrm{~nm}$ relative to the compensation solution 1 .

Absorbance of the reference solution relative to the compensation solution 2 os measured simultaneously.

The content of the sum of flavonoids calculated as luteolin in percentages is calculated by the formula:

$$
X=\frac{A_{1} \times m_{0} \times 20 \times P}{A_{0} \times m \times 100},
$$

where $A_{1}$ - absorbance of the test solution at wavelength of $410 \mathrm{~nm} ; \mathrm{A}_{0}-$ absorbance of the reference solution at wavelength of $410 \mathrm{~nm} ; \mathrm{m}_{0}$ - luteolin Pharmacopoeial standard sample SPhU weight, in grams; $\mathrm{m}$ - herbal sample weight, in grams; $\mathrm{P}-$ the content of luteolin in luteolin Pharmacopoeial standard sample, in percentages.

7 samples of the herbal material were analyzed by the given method. Every sample was studied three times. Results are displayed in Table 2. Typical absorption spectra of the herb sample № 4 test solution and luteolin standard sample solution are shown in Fig. 1.

The obtained results have shown that № 1 and № 2 samples were characterized by the lowest content of flavonoids $0.09 \%$, which may indicate incorrect either harvesting or storage of herbal material. This assumption was also confirmed by macroscopic analysis results of the given samples, which showed the disparity of the analyzed samples according to the regulated color.

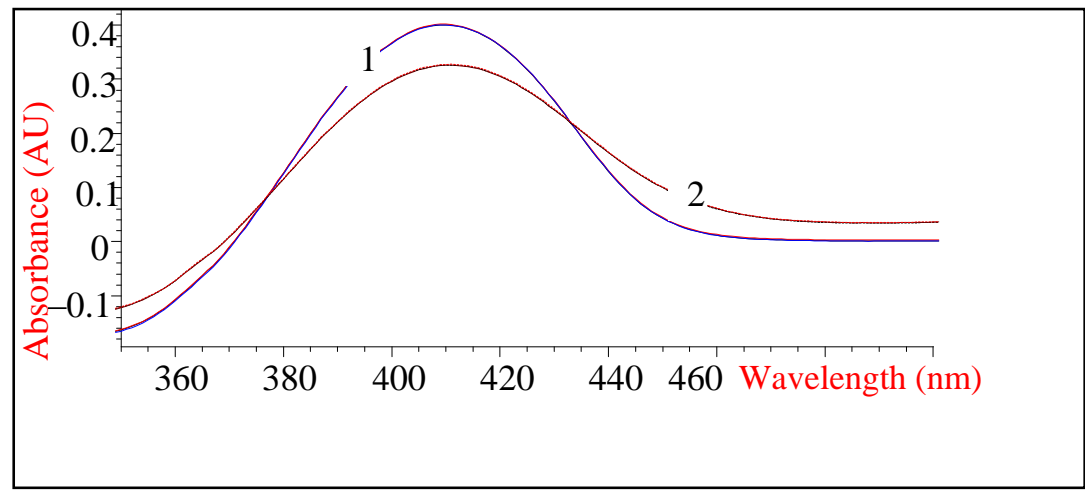

Fig. 1. Typical absorption spectra obtained in conditions of the developed quantitative determination method: 1 - the solution of luteolin Pharmacopoeial standard sample SPhU, 2 - Corn silk № 4 sample test solution

Table 2

The content of flavonoids in Corn silk samples

\begin{tabular}{|c|c|c|}
\hline No. & RS & The content of flavonoids X, \% calculated as luteolin and dry material \\
\hline 1 & 684 & $0.09 \pm 0.003 \%$ \\
\hline 2 & 685 & $0.09 \pm 0.002 \%$ \\
\hline 3 & 686 & $0.60 \pm 0.03 \%$ \\
\hline 4 & 687 & $0.93 \pm 0.06 \%$ \\
\hline 5 & 688 & $0.70 \pm 0.02 \%$ \\
\hline 6 & 689 & $0.61 \pm 0.03 \%$ \\
\hline 7 & 690 & $1.08 \pm 0.06 \%$ \\
\hline
\end{tabular}

\section{Conclusion}

1. Quantitative content of flavonoids calculated as luteolin in seven samples of Corn silk was analyzed by spectroscopy method.

2. The content of flavonoids in 7 studied samples was determined within $0.60-1.08 \%$.
3. In result of the research, it was suggested to implement the method for quantitative determination of flavonoids, calculated as luteolin, with regulation of not less than $0.6 \%$, into the State Pharmacopoeia of Ukraine national monograph "Corn silk".

\section{References}

1. Guideline on good agricultural and collection practice (GACP) for starting materials of herbal origin [Text]. - European Medicines for Human Use. - London: EMEA, 2006. - 11 p.

2. Derzhavna Farmakopeya Ukrayiny. Vol. 3 [Text]. - Kharkiv: Derzhavne pidpryyemstvo "Ukrainskyi naukovyi farmakopeynyy tsentr yakosti liarskih zasobiv", 2014. - $732 \mathrm{p}$.

3. Guide for the elaboration of monographs oh herbal drugs and herbal preparations [Text]. - European Directorate for the Quality of Medicines, Strasbourg Cedex. - France, 2007. - 22 p.

4. Grizodub, A. I. Problemyi vvedeniya monografiy na lekarstvennoe rastitelnoe syire v Gosudarstvennuyu Farmakopeyu Ukrainyi [Text] / A. I. Grizodub, G. V. Georgievskiy, T. M. Tihonenko, V. P. Georgievskiy // Farmakom. - 2004. - Vol. 4. - P. 3-17.

5. Bisset, N. G. Herbal drugs and phytopharmaceuticals: a handbook for practice on a scientific basis [Text] / N. G. Bisset, M. Wichtl. - Stuttgart: Medpharm Scientific Publishers, 1994. - 342 p.

6. Kompendium [Electronic resource]. - Available at: http://compendium.com.ua/

7. Lebeda, A. F. Lekarstvennyie rasteniya. Samaya polnaya entsyiklopediya [Text] / A. F. Lebeda, N. I. Dzhurenko, A. P. Isaikina, V. G. Sobko. - Moscow: AST-PRESS KNIGA, 2010. - 496 p. 
8. Gosudarstvennaya farmakopeya SSSR. Obschin metodyi analiza. Lekarstvennoe rastitelnoe syire [Text]. - Moscow: Medicine, 1989. - $400 \mathrm{p}$.

9. Gosudarstvennaya farmakopeya Respubliki Belarus. Vol. 2. Kontrol kachestva vspomogatelnyih veshestv i lekarstvennogo ratitelnogo syirya [Text]. - Moscow: Pobeda, 2008. - 1345 p.

10. Pharmacopee Francaise XI ed. [Electronic resource]. - Available at: www.http://ansm.sante.fr/Mediatheque/Publications/ Pharmacopee-francaise-Plan-Preambule-index

11. British Herbal Pharmacopea [Text]. - British Herbal Medicine Association. - Bristol, 1996. - 212 p.

12. Karpiuk, U. V. Peredumony rozrobky monohrafiyi «Kukurudzy stovpchyky z pryimochkamy» dlya vvedennya do Derzhavnoyi farmakopeyi Ukrayiny [Text] / U. V. Karpiuk, V. S. Kyslychenko, A. H. Kotov, E. E. Kotova // Phitoterapiya. Chasopys. - 2017. - Vol. 1. - P. 24-27.

13. European Pharmacopoeia. 7 ed. [Text]. - Strasbourg: European Department for the Quality of Medicines, 2009.

14. Kotov, A. H. Doslidzhennya z rozrobky ta vvedennya monohrafiy na likars'ku roslynnu syrovynu do Derzhavnoyi farmakopeyi Ukrayiny [Text] / A. H. Kotov // Farmakom. - 2009. - Vol. 1. - P. 5-19.

15. Kotova, E. E. Systematyzatsiya farmakopeynykh vymoh do metodiv kontrolyu yakosti likars'koyi roslynnoyi syrovyny. Unifikovani spektrofotomertychni metodyky [Text] / E. E. Kotova, A. H. Kotov // Farmakom. - 2014. - Vol. 4. - P. 22-34

16. Karpiuk, U. (2017). Development of method for qualitative analysis of corn silk for implementation in the state pharmacopoeia of Ukraine draft national monograph [Text] / U. Karpiuk, E. Kotova, A. Kotov, V. Kyslychenko // ScienceRise: Pharmaceutical Science. - Vol. 3, Issue 7. - P. 25-31. doi: 10.15587/2519-4852.2017.103906

17. Derzhavna Farmakopeya Ukrayiny. Vol. 1 [Text]. - Kharkiv: Derzhavne pidpryyemstvo "Naukovo-ekspertnyy farmakopeynyy tsentr", 2001. - 556 p.

18. Derzhavna Farmakopeya Ukrayiny. Vol. 1. Dop. 2 [Text]. - Kharkiv: Derzhavne pidpryyemstvo "Naukovo-ekspertnyy farmakopeynyy tsentr", 2008. - 620 p.

19. Kotova, E. E. Standartizatsiya travyi dushitsyi po kolichestvennomu soderzhaniyu flavonoidov [Text] / E. E. Kotova, N. I. Tihonenko, A. G. Kotov // Aktualni pytannia farmatsevtychnoi ta medychnoi nauky ta praktyky. - 2011. - Vol. 24, Issue 3. P. $38-42$.

20. Zolotaikina, M. Yu. Development of method for quantitative determination of phenolic compounds in tansy flowers [Text] / M. Yu. Zolotaikina, T. M. Hontova, E. E. Kotova, A. H. Kotov, S. M. Hubar // ScienceRise: Pharmaceutical Science. - 2016. - Vol. 1, Issue 1. - P. 34-40. doi: 10.15587/2519-4852.2016.72696

Дата надходження рукопису 10.05.2016

Uliana Karpiuk, PhD, Associate Professor, Department of pharmacognosy and botany, Bogomolets National Medical University, T. Shevchenka blvd., 13, Kyiv, Ukraine, 01601

E-mail: uliana.karpiuk@gmail.com

Elina Kotova, PhD, Senior Researcher, Head of Sector., Sector "Experimental support for the development of monographs of SPhU", SE "Ukrainian Scientific Pharmacopoeial Center for the Quality of Medicines", Asrtonomichna str., 33, Kharkiv, Ukraine, 61085

E-mail: kotova@phukr.kharkov.ua

Andriyi Kotov, Doctor of Pharmacuetical Sciences, Senior Researcher, Head of Department, Department of State Pharmacopoeia of Ukraine, SE "Ukrainian Scientific Pharmacopoeial Center for the Quality of Medicines", Asrtonomichna str., 33, Kharkiv, Ukraine, 61085

E-mail: kotov@phukr.kharkov.ua

Victoriya Kyslychenko, Doctor of Pharmacuetical Sciences, Professor, Head of Department, Department of Chemistry of natural compounds, National University of Pharmacy, Pushkinska str., 53, Kharkiv, Ukraine, 61002 E-mail: cnc@ukrfa.kharkov.ua 